\title{
Application of inventory data for estimating characteris- tics of and regional climate-change effects on mountain glaciers: a pilot study with the European Alps
}

\author{
Wilfried Haeberli and Martin Hoelzle \\ Laboratory of Hydraulics, Hydrology and Glaciology, Federal Instilute of Technology (ETH), CH-8092 Zürich, \\ Switzerland, and World Glacier Monitoring Service (GEMS/UNEP, IHP/UNESCO, FAGS/ICSU, ICSI/IAHS)
}

\begin{abstract}
A parameterization scheme using simple algorithms for unmeasured glaciers is being applied to glacier inventory data to estimate the basic glaciological characteristics of the inventoried ice bodies and simulate potential climate-change effects on mountain glaciers. For past and potential climate scenarios, glacier changes for assumed mass-balance changes are calculated as step functions between steadystate conditions for time intervals that approximately correspond to the characteristic dynamic response time (a few decades) of the glaciers. In order to test the procedure, a pilot study was carried out in the European Alps where detailed glacier inventories had been compiled around the mid-1970s. Total glacier volume in the Alps is estimated at about $130 \mathrm{~km}^{3}$ for the mid-1970s; strongly negative mass balances are likely to have caused a loss of about $10-20 \%$ of this total volume during the decade 1980 90. Backward calculation of glacier-length changes using a mean annual mass balance of $0.25 \mathrm{~m}$ w.e. $\mathrm{a}^{-1}$ since the end of the "Little Ice Age" around $1850 \mathrm{AD}$ gives considerable scatter but satisfactory overall results as compared with long-term observations. The total loss of Alpine surface ice mass since 1850 can be estimated at about half the original value. An acceleration of this development, with annual mass losses of around $1 \mathrm{~m} \mathrm{a}^{-1}$ or more as anticipated from IPCC scenario A for the coming century, could eliminate major parts of the presently existing Alpine ice volume within decades.
\end{abstract}

\section{INTRODUCTION}

An extensive data base on topographic glacier parameters has been built up in regional glacier inventories (Haeberli and others, 1989). Repetition of such glacier inventory work is planned at time intervals comparable to the characteristic dynamic response times of mountain glaciers (a few decades). This should help with analyzing changes at a regional scale and with assessing the representativeness of continuous measurements which can only be carried out on a few selected glaciers. In addition, glacier inventory data serve as a statistical basis for extrapolating the results of observations or model calculations concerning individual glaciers (Oerlemans, 1993, 1994) and to simulate regional aspects of past and potential climate-change effects. This latter application requires the introduction of a parameterization scheme using simple algorithms for unmeasured glaciers. A corresponding scheme is explained and illustrated with the example of the European Alps. The procedure described also enables plausibility checks to be carried out on the large sample of inventory data and is presently being systematically applied while loading available detailed inventories into the new data bank of the World Glacier Monitoring Service (WGMS) (paper in preparation by M. Hoelzle and M. Trindler).

\section{PARAMETERIZATION SCHEME}

The basis for the parameterization scheme (cf. Hoelzle (1994) for more detailed discussion) consists of measured inventory data on the total length $\left(L_{0}\right)$, maximum/ minimum altitude $\left(H_{\max }, H_{\min }\right)$ and total surface area $(F)$ of the investigated glaciers. From these basic parameters, mean altitude $\left(H_{\mathrm{m}}=\left[H_{\max }-H_{\min }\right] / 2\right)$, vertical extent $\left(\Delta H=H_{\max }-H_{\min }\right)$ and average surface slope $\left(\alpha=\arctan \left[\Delta H / L_{0}\right]\right)$ are derived as a first step. The length of the central flowline in the ablation area $\left(L_{\mathrm{a}}\right)$ is empirically set as $0.5 L_{0}$ (Müller, 1988) for glaciers $\leq 2 \mathrm{~km}$, and as $0.75 L_{0}$ for glaciers $>2 \mathrm{~km}$. The mean slope of the ablation area $\left(\alpha_{\mathrm{a}}\right)$ is then computed from $\arctan \left(H_{\mathrm{m}}-H_{\min }\right) / L_{\mathrm{a}}$. Average ice depth along the central flowline $\left(h_{\mathrm{f}}\right)$ is estimated from $\alpha$ and a mean basal shear stress along the central flowline $\left(\tau_{\mathrm{f}}=f \rho g h_{\mathrm{f}} \sin \alpha\right.$, where $\rho$ is density and $g$ is acceleration due to gravity) which depends in a non-linear way on $\Delta H$ as a function of mass turnover (Fig. 1; cf. Haeberli, 1985; Driedger and Kennard, 1986). The shape factor $f$ is chosen as 0.8 for all glaciers. Ice thickness in the ablation area $\left(h_{\mathrm{f}, \mathrm{a}}\right)$ is derived from $\tau_{\mathrm{f}}$ and $\alpha_{\mathrm{a}}$ and maximum thickness $\left(h_{\max }\right)$ is very roughly determined at $2.5 h_{\mathrm{f}, \mathrm{a}}$, as estimated from known ice thickness measurements on various Alpine glaciers (Müller and others, 1976; unpublished radio-echo soundings/hot-water drillings by VAW/ETH Zürich) 


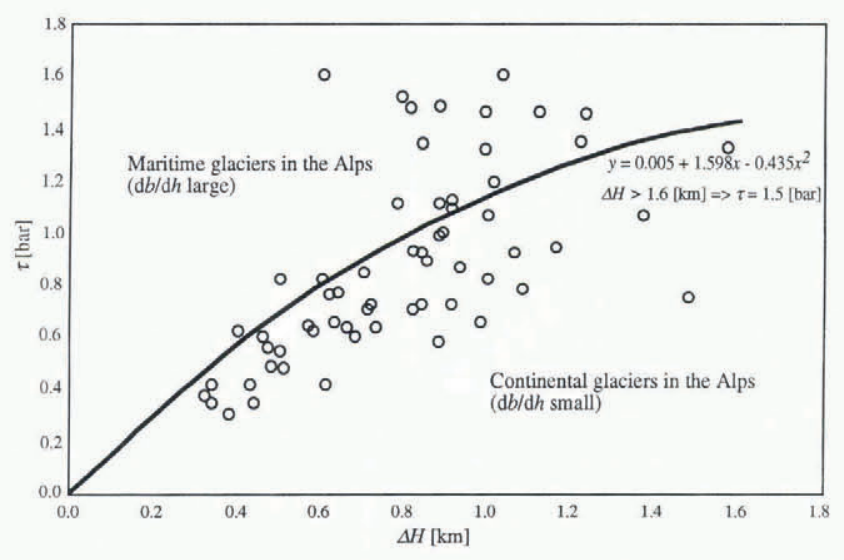

Fig. 1. Average basal shear stress along the central flowline is altitudinal extent of (reconstructed latePleislocene Alpine) glaciers (modified from Haeberli (1985)). The polynomial fit gives the function used in the present study. A maximum value of 1.5 bar $(150 \mathrm{kPa})$ was assumed for the largest glaciers.

and in order to account for some longitudinal variations in $\alpha$. Average thickness of the entire (three-dimensional) glacier is assumed to be $h_{\mathrm{F}}=(\pi / 4) h_{\mathrm{f}}$ in accordance with a semi-elliptic cross-sectional geometry. Total glacier volume then becomes $V=F h_{\mathrm{F}}$.

Mean altitude $\left(H_{\mathrm{m}}\right)$ is taken as an approximation for equilibrium-line altitude (ELA; cf. Braithwaite and Müller, 1980), and the mass balance (annual ablation) at the glacier tongue is computed as $b_{\mathrm{t}}=\mathrm{d} b / \mathrm{d} H$ $\left(H_{\mathrm{m}}-H_{\min }\right)$ where the mass-balance gradient $\mathrm{d} b / \mathrm{d} H$ receives a value of $0.75 \mathrm{~m}$ w.e. per $100 \mathrm{~m}$ and year for the ablation area, as appears quite characteristic for the Alps Oerlemans and Hoogendorn, 1989; Oerlemans and Fortuin, 1992). Depth-averaged mean flow velocity along the central flowline in the ablation area is calculated as balance velocity for the lower half of the ablation area as $u_{\mathrm{m}, \mathrm{a}}=\left[\left(3 b_{\mathrm{t}} / 4\right)\left(L_{\mathrm{a}} / 2\right)\right] / h_{\mathrm{f}, \mathrm{a}}$. For simplicity, the corresponding surface flow velocity $u_{\mathrm{s}, \mathrm{a}}$ is assumed not to differ significantly from $u_{\mathrm{m}, \mathrm{a}}$; its component of ice deformation is calculated from $u_{\mathrm{d}, \mathrm{a}}=2 A \tau_{\mathrm{f}}^{\mathrm{n}} h_{\mathrm{f}} /(n+1)$ where $A$ is uniformly chosen as $0.16 \mathrm{a}^{-1} \mathrm{bar}^{-3}$ and $n=3$ to give realistic values (cf. Paterson, 1981). The combined consideration of mass conservation and the ice-flow law would, in principle, allow the sliding velocity in the ablation area to be estimated as $u_{\mathrm{b}, \mathrm{a}}=u_{\mathrm{s}, \mathrm{a}}-u_{\mathrm{d}, \mathrm{a}}$. The velocity ratio in the ablation area would then be defined as $u_{\text {b.a }} / u_{\text {s.a. }}$. In view of the limited data base and the uncertainties involved with the flow-law parameters, however, firm conclusions cannot be expected from such dynamic considerations.

Glacier-length changes $\left(\delta L=L_{0} \delta b / b_{\mathrm{t}}\right.$; cf. Paterson, 1981; Haeberli, 1994) for given disturbances in mass balance $(\delta b)$ are calculated with respect to the characteristic dynamic response time $t_{\text {resp }}=h_{\max } / b_{\mathrm{t}}$ (cf. Jóhannesson and others, 1989) in the sense of step functions between steady-state conditions. The reaction time between the onset of $\delta b$ and the first reaction at the glacier terminus is estimated as $t_{\text {react }}=L_{\mathrm{a}} / c$, where $c$ is the kinematic wave velocity (Nye, 1965). The application of kinematic wave theory is especially delicate (Lliboutry and Reynaud, 1981), but the reaction times calculated with $c=4 u_{\text {s.a }}$ seem to compare quite well with observed advance patterns (Müller, 1988). The time interval between the first reaction at the glacier terminus and full response to $\delta b$ is called relaxation time (paper in preparation by T.J.H. Chinn ): $t_{\text {relax }}=t_{\text {resp }}-t_{\text {react }}$.

Near-surface thermal regime $(10 \mathrm{~m}$ temperature) is defined from empirical relations between mean annual air, firn and ice temperatures (Haeberli and Alean, 1985) in the following way: cold firn is believed to exist everywhere above the $-12^{\circ} \mathrm{C}$ mean annual air-temperature isotherm, and ablation areas are expected to be partially cold where mean annual air temperature at the ELA $\left(H_{\mathrm{m}}\right)$ is below $4 \mathrm{C}$. This first-order approach could be improved by using a relation between $10 \mathrm{~m}$ ice and mean summer air temperatures (Hooke and others, 1983).

\section{PRESENT-DAY GLACIERIZATION}

The data for the European Alps as used in the present study and containing a total of 5050 perennial surface ice bodies were compiled for the mid-1970s Austria 1969, France 1967-71, Germany 1979, Italy 1975-84, Switzerland 1973). Only 1763 of these ice bodies (35\%) are glaciers larger than $0.2 \mathrm{~km}^{2}$ with complete information available about surface area, total length and maximum and minimum altitude. The above-explained parameterization scheme is applied to this part of the sample. The remaining 3287 ice bodies $(65 \%)$ are perennial ice patches and glacierets smaller than $0.2 \mathrm{~km}^{2}$ and are treated separately.

The total surface area of all 5050 inventoried surface ice bodies is $2909 \mathrm{~km}^{2}$ (Haeberli and others, 1989). The surface area of the 1763 glaciers $>0.2 \mathrm{~km}^{2}$ is $2533 \mathrm{~km}^{2}$, or $88 \%$ of the total surface area. The total volume of these glaciers $>0.2 \mathrm{~km}^{2}$ is calculated as $126 \mathrm{~km}^{3}$, that of the 3287 glacierets $\leq 0.2 \mathrm{~km}^{2}$ as $2.6 \mathrm{~km}^{3}$. The latter value is globally estimated by taking half $(7.5 \mathrm{~m})$ the mean value of $h_{\mathrm{F}}(15 \pm 4 \mathrm{~m})$ for glaciers with $0.2<\mathrm{F}<0.4 \mathrm{~km}^{2}$. The overall volume of perennial surface ice in the Alps around 1970 is thus about $130 \mathrm{~km}^{3}$. Complete melting of this ice volume would cause a sea-level rise of about $0.35 \mathrm{~mm}$. Such a small value is not of great importance for sea-level rise but suggests the vulnerability to climate effects of glaciers in comparable high mountain areas with predominantly small glaciers. The decade 198090 with a mean annual mass balance of $-0.65 \mathrm{~m}$ w.e. as measured on eight regularly observed glaciers in the Alps Caréser, Gries, Hintereis, Kesselwand, Saint Sorlin, Sarennes, Silvretta, Sonnblick; Haeberli and Müller, 1988; Haeberli and Hoelzle, 1993; cf. Haeberli, 1994) may have brought about a loss in surface ice volume of nearly $20 \mathrm{~km}^{3}$ or about $10-20 \%$ of the total volume existing around 1970 . It is reasonable to assume that the total volume of perennial Alpine surface ice is now (1994) not much higher than $100 \mathrm{~km}^{3}$. Comparably low total glacier volumes may have existed around $1950 \mathrm{AD}$, around $4000 \mathrm{BP}$ and around $5000 \mathrm{BP}$; even smaller ice volumes can possibly be attributed to the early Holocene, i.e. the time period around $70006000 \mathrm{BP}$ (Haeberli, 1994).

A number of interesting glaciological characteristics can also be derived with respect to the investigated sample of Alpine glaciers (Fig. 2). Only 54 (3\%) of the 

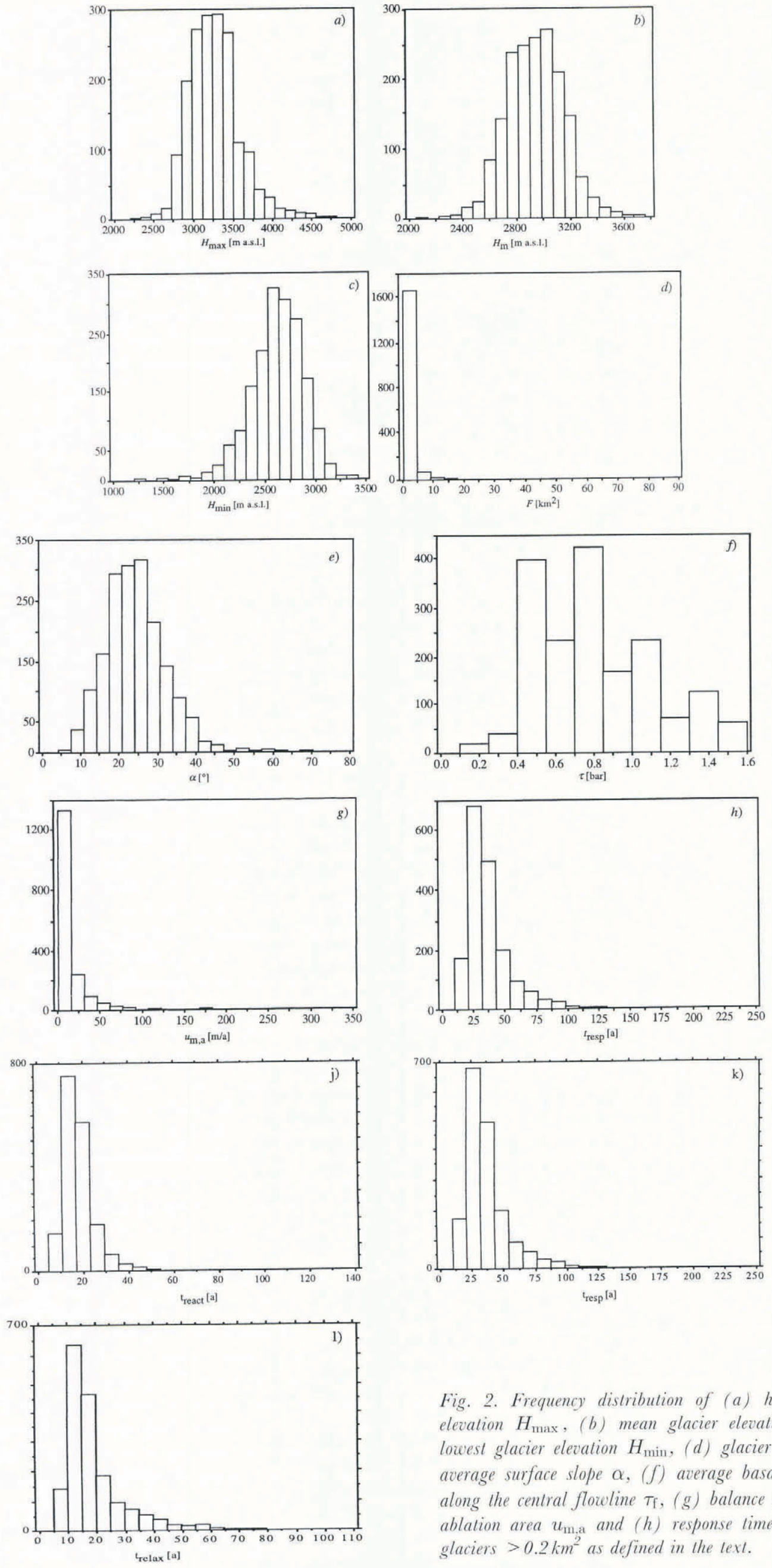

Fig. 2. Frequency distribution of (a) highest glacier elevation $H_{\max }$, (b) mean glacier elevation $H_{\mathrm{m}}$, (c) lowest glacier elevation $H_{\min }$, (d) glacier area $F$, (e) average surface slope $\alpha,(f)$ average basal shear stress along the central flowline $\tau_{\mathrm{f}},(\mathrm{g})$ balance velocity in the ablation area $u_{\mathrm{m} . \mathrm{a}}$ and $(h)$ response time $t_{\mathrm{resp}}$ for the glaciers $>0.2 \mathrm{~km}^{2}$ as defined in the lext. 
1763 glaciers $>0.2 \mathrm{~km}^{2}$ begin above $4000 \mathrm{~m}$ a.s.l. and, hence, definitely have parts of cold firn in their accumulation areas. On the other hand, $1323(75 \%)$ of all glaciers $>0.2 \mathrm{~km}^{2}$ have ELAs (mean altitudes) above $2800 \mathrm{ma.s.1}$, where mean annual air temperature is around $-4 \mathrm{C}$. This means that for the most part the Alpine glaciers are not strictly temperate but rather polythermal with more or less extended cold parts (surface layers) in their ablation areas. Most glaciers $(88 \%)$ have mean annual air temperatures at the equilibrium line between $-2^{\circ}$ and $-6^{\circ} \mathrm{C} \quad\left(2500 \leq H_{\mathrm{m}}\right.$ $\leq 3200$ ), indicating transitional climatic conditions as opposed to maritime $\left(>-2{ }^{\circ} \mathrm{C}, 2 \%\right)$ and continental $\left(<-6^{\circ} \mathrm{C}, 10 \%\right)$ types of glaciers (cf. Haeberli, 1983). More than four out of five glaciers $(83 \%)$ end above $2400 \mathrm{~m}$ a.s.l., i.e. in the altitudinal belt where discontinuous permafrost regularly occurs. More than $90 \%$ of the glaciers $>0.2 \mathrm{~km}^{2}$ have total surface areas smaller than $10 \mathrm{~km}^{2}$, lengths shorter than $5 \mathrm{~km}$ and overall slopes steeper than $10^{\circ}$. This means that the sample of presently existing Alpine glaciers is dominated by small and steep mountain glaciers with average thicknesses of a few tens of metres. About $70 \%$ of these small mountain glaciers have average basal shear stresses along the central flowline which remain below 1 bar $(100 \mathrm{kPa})$. Such rather static ice bodies, called "glaciers réservoirs" by Lliboutry (unpublished), react through (vertical) surface altitude changes rather than pronounced (horizontal) advance/ retreat as can be typically observed for the more dynamic, rapidly flowing "glaciers vacuateurs" with higher basal shear stresses ( $>1$ bar, or $>100 \mathrm{kPa}$ ). Calculated surface velocities in the ablation areas of the small mountain glaciers are typically a few tens of metres. Response times centre around a few decades and are a strongly non-linear function of surface slope (Fig. 3). This result is mainly related to the parameterization applied in the present study but could also be physically reasonable: with slope decreasing towards the horizontal, the difference between equilibrium-line and terminus altitudes here: $\left.H_{\mathrm{m}}-H_{\min }\right)$ and, hence, ablation at the terminus tends to become zero and the response time tends to become indefinitely long because a non-flow condition is being approached. On the other hand, slopes increasing towards the vertical reduce maximum thickness to zero and asymptotically shorten response times towards zero. In such cases, mass transfer on steep to vertical walls is by instabilities and falling of snow and ice rather than by steady ice flow. Reaction time varies from a few years to a few decades and tends to be one-third to two-thirds of the response time, the higher fraction being more characteristic for the smaller glaciers. Derived relaxation time has a peak frequency around 10 years with decreasing probabilities for longer time intervals.

\section{SIMULATION OF CLIMATE-CHANGE EFFEGTS}

A first experiment was run to simulate maximum glacier extent around $1850 \mathrm{AD}$, the end of the "Little Ice Age" in central Europe, in order to check how realistic the proposed scheme is as compared to observed long-term changes and then to simulate changes that have happened since. The considered time interval is 120 130 years. In view of the fact that Alpine glaciers remained quite unchanged between 1890 and 1925 (Patzelt and Aellen, 1990), the time interval since the middle of the past century spans about twice the characteristic mean response time of the investigated sample of Alpine glaciers. Instead of calculating two subsequent steps with increasing uncertainties about the parameters involved (for instance, ablation at the glacier tongue in times lacking measurements), one single step with a positive mass-balance (step) change of $1 \mathrm{ma}^{-1}$ was assumed for the entire time interval. This procedure corresponds to a calculation with two steps assuming two full dynamic responses (for instance, 1850-1900 and $1930-80)$ to a step change in mass balance of $0.5 \mathrm{~m} \mathrm{a}^{-1}$ and an average balance of $0.25 \mathrm{~m} \mathrm{a}^{-1}$ for both partial intervals. The comparison between calculated and measured length changes for selected glaciers (Table 1) shows that the different sensitivities of long-term glacier length as a response to uniform mass-balance forcing can

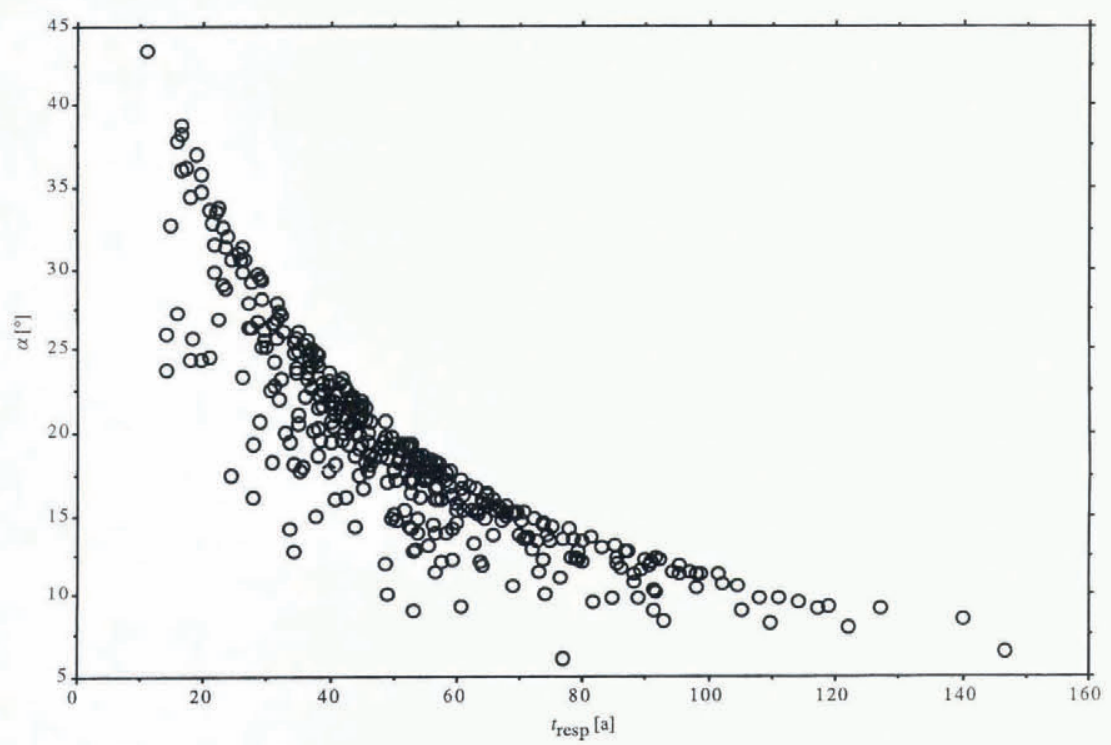

Fig. 3. Response times $t_{\text {resp }}$ as a function of average surface slope $\alpha$ for glaciers longer than $2 \mathrm{~km}$. 
Table 1. Measured and calculated cumulative length changes and average mass balances of selected Alpine glaciers since $1850 \mathrm{AD} . \delta L_{\mathrm{m}}$, measured cumulative length change, 1850-1970 AD; $\delta L_{\mathrm{c}}$, calculated total length change, $1850-90$ and 1925-70 with a mean mass balance of $-0.25 \mathrm{~m}$ w.e. $a^{-1}$ for both partial time intervals; $b^{*}$, average mass balance, 1850-90 and 1925-70 as corrected by $\delta L_{\mathrm{m}} / \delta L_{\mathrm{c}}$ for the measured length change

\begin{tabular}{|c|c|c|c|c|c|}
\hline Glacier & $\begin{array}{c}\delta L_{\mathrm{m}} \\
\mathrm{km}\end{array}$ & $\begin{array}{l}\delta L_{\mathrm{c}} \\
\mathrm{km}\end{array}$ & $\delta L_{\mathrm{m}} / \delta L_{\mathrm{c}}$ & $\begin{array}{c}b^{*} \\
\text { m w.e. } a^{-1}\end{array}$ & Source for $\delta L_{\mathrm{m}}$ \\
\hline
\end{tabular}

\begin{tabular}{llllll}
\hline Aletsch & 2.5 & 2.5 & 1.00 & -0.25 & Aellen (1981) \\
Argentière & 0.8 & 0.9 & 0.89 & -0.22 & Bless (1984) \\
Gepatsch & 1.7 & 1.6 & 1.06 & -0.27 & Haeberli and Müller (1988) \\
Gurgler & 2.3 & 1.9 & 1.21 & -0.30 & Haeberli and Müller (1988) \\
Hintereis & 2.2 & 1.6 & 1.38 & -0.35 & Haeberli (1985) \\
Hüfi & 2.6 & 1.3 & 2.00 & -0.50 & Aellen (1981) \\
Langtaler & 1.2 & 1.4 & 0.86 & -0.22 & Haeberli and Müller (1988) \\
Morteratsch & 1.9 & 1.0 & 2.00 & -0.50 & Maisch (1992) \\
Oedenwinkel & 1.4 & 0.9 & 1.56 & -0.39 & Haeberli and Hoelzle (1993) \\
Rhone & 2.2 & 1.8 & 1.22 & -0.31 & Aellen (1981) \\
Tour & 1.1 & 1.1 & 1.00 & -0.25 & Bless (1984) \\
Trient & 1.2 & 0.8 & 1.50 & -0.38 & Bless (1984) \\
Upper Grindelwald & 0.8 & 0.6 & 1.33 & -0.33 & Aellen (1981) \\
Mean & & & 1.31 & -0.33 & \\
S.d. & & & 0.38 & 0.09 & \\
& & & & & \\
\hline
\end{tabular}

be quite well reproduced (cf., for instance, Upper Grindelwald and Aletsch) and that the chosen massbalance forcing appears to underestimate slightly the real evolution. Differences between measured and calculated overall length change for individual glaciers, on the other hand, can be considerable and are explained by uncertainties in the simple parameterization scheme applied, by the limited data base available for each glacier in inventories, and by variable climate/massbalance conditions at each glacier. Correcting the massbalance forcing for each glacier to fit the measured length change gives an average mass balance of $0.33 \pm 0.09 \mathrm{~m} \mathrm{a}^{-1}$ average (secular) mass loss for the sample of glaciers considered in Table 1. If the time period 1850-1970 is treated as one single retreat period without consideration of the 35 years of stationary glaciers, the above calculated value reduces to an average mass loss of $0.2-0.3 \mathrm{~m}$ w.e. $\mathrm{a}^{-1}$. The energy required for melting this amount of ice during the time interval $1850-1970 \mathrm{AD}$ is $2-3 \mathrm{~W} \mathrm{~m}^{-2}$. Such values roughly correspond to the observed long-term trend of atmospheric warming and could be quite representative of (non-polar?) mountain glaciers all over the world (Oerlemans, 1994).

The calculated length change divided by two relaxation times for the two periods considered gives characteristic average rates of length change during marked advance/retreat periods of a few tens of meters per year with steep/high-stress glaciers such as Bionnassey, Taconnaz, Bosson, Brenva, Miage, Lower Grindelwald and Belvédère being among the most active ones and relatively flat, plateau-like glaciers such as Caréser and Sarsura belonging to the most inert ones. The total glacier area for $1850 \mathrm{AD}$ was calculated for the glaciers $>0.2 \mathrm{~km}^{2}$ from $F_{1850}=0.002+0.285 L_{1850}+0.219$
$\left(L_{1850}\right)^{2}-0.004\left(L_{1850}\right)^{3}$, where $L_{1850}$ is the inferred length at the end of the "Little Ice Age". The thirddegree polynomial fit to the data was chosen in order to avoid negative area values for the smallest glaciers and to optimally reproduce the length/area relation for Aletsch, by far the largest Alpine glacier. The so-calculated $F_{1850}$ is at least 1.5 times the area calculated for the mid-1970s but neglects not only the area changes for ice bodies $<0.2 \mathrm{~km}^{2}$ in the presently existing inventories but also all ice bodies that completely vanished before the mid-1970s. It is therefore reasonable to assume that at least $35 \%$ of the glacierized surface area existing around 1850 has disappeared. The corresponding volume change as estimated by multiplying the mass-balance forcing $0.25 \mathrm{~m} \mathrm{a}^{-1}$ over the entire time interval of 125 years, as explained above) with the average area $\left(F+F_{1850}\right) / 2$ yields a volume change of at least $45-50 \%$. After the mass losses of the decade 1980 90, somewhat more than half the volume of ice originally existing around 1850 has probably disappeared by now (1994).

In a second step, calculations were made with a massbalance forcing of $-0.9 \mathrm{ma}^{-1}$ during a time interval of 50 years and starting from the conditions of the mid1970 s. This could more or less correspond to the consequences of IPCC scenario A (business as usual) till $2025 \mathrm{AD}$ with an acceleration by a factor of 3-4 with respect to the evolution since about 1920 (Kuhn, 1989, 1990 ). In such a scenario, 441 small glaciers representing $25 \%$ of the glaciers $>0.2 \mathrm{~km}^{2}$ existing in the detailed Alpine inventories from the mid-1970s would disappear because their length would be reduced to zero, the equilibrium line would rise above their highest point and/ or their maximum thickness would be exceeded by cumulative mass losses. In comparison with conditions 
in the mid-1970s, about one-third of the surface area and more than half the ice volume would be lost. This means that less than half the surface area and about one-quarter of the ice volume could be left in the year 2025 from the Alpine ice cover existing at the end of the "Little Ice Age". Because surface area in the initial decades of the considered time interval is still relatively extended, roughly one-third of the simulated volume loss between the mid-1970s and the year 2025 may already have occurred since about 1980.

Due to increasing uncertainties and pronounced nonlinearities such as changing response times with changing glacier size, etc., calculations for scenarios of continued acceleration tendencies of the climate and mass-balance forcing beyond the early decades of the 21 st century can be order-of-magnitude estimates only. Annual mass losses of $1-2 \mathrm{ma}^{-1}$ as must be expected from IPCC scenario A would reduce the surface area and volume of Alpine glaciers to a few per cent of the values estimated for the "Little Ice Age" maximum by the second half of the 21st century. With such a development, only the largest and highest-reaching Alpine glaciers could persist into the 22 nd century, and these glaciers would be affected by drastic changes in geometry. Down-wasting rather than active retreat would thereby probably be the predominant process involved.

\section{DISCUSSIONS AND CONCLUSIONS}

The calculations and estimations presented in this study build on four simple geometric parameters contained in detailed inventories. This justifies the simplicity of the applied algorithms but also means that uncertainties involved with the proposed procedure are considerable. In fact, the large scatter in derived parameters such as flow velocities, response times, etc., points to the fact that the applied parameterization scheme is more useful for relatively large glaciers than for small ice bodies. The large glaciers, on the other hand, have a predominant influence on overall mass changes and, hence, make the estimates of corresponding changes probably quite realistic. IPCC scenario A may give upper-bound values concerning potential future evolutions, and less dramatic scenarios are possible as well. In any case, however, the striking sensitivity of glacierization in cold mountain areas with respect to atmospheric warming trends clearly appears.

The proposed scheme needs further investigation and application. As a next step, detailed discussion and sensitivity analysis will be carried out with respect to the various assumptions and simplifications introduced, especially concerning ice depth and volume calculations as well as estimates of flow velocities and response characteristics. In addition, adaptation possibilities of empirical/regional approaches involved (e.g. characteristic balance gradients, ablation area length) must be checked to see whether they can be applied to other mountain ranges. It is planned to make similar analyses for all available detailed glacier inventories while loading them into the new data bank and to check the data base in cooperation with the responsible national correspondents of WGMS. The possibilities are also presently being investigated of retrieving additional information on glacier dynamics (down-wasting/retreat, rock/sediment beds, etc.) or hydrology (seasonal run-off variations, etc.). Perhaps the most important possibility is of quantitatively inferring average decadal mass balances for unmeasured glaciers by analyzing cumulative length change from field evidence (moraine mapping, satellite imagery, aerial photography, long-term observations). The repetition of detailed regional glacier inventories would thereby not only furnish important information on local to regional environmental changes but also provide the basis for evaluating scenarios of global warming.

\section{ACKNOWLEDGEMENTS}

The present study was carried out as part of the data analysis work for WGMS, with special grants from UNEP/GEMS through Project No. FP/9101-87-62 (2896) Rev. 7 and FAGS/ICSU, and as part of the Swiss National Research Programme on Climate Change and Natural Catastrophes through Project No. 403134232 with funds from the Swiss National Science Foundation. Special thanks are due to Professor Vischer, Director of the Laboratories of Hydraulics, Hydrology and Glaciology (VAW) at ETH Zürich, for his continued interest and encouragement. M. Aellen, H. Gudmundsson, Andreas Kääb and D. Vonder Mühll at VAW and M. Kuhn, M. Meier, G. Ostrem and V. Popovnin as consultants to WGMS critically read the manuscript.

\section{REFERENCES}

Aellen, M. 1981. Recent fluctuations of glaciers. In Kasser, P. and W. Hacberli, eds. Swilzerland and her Glaciers: from the Ice. Age to the Present. Zürich, Switzerland, Swiss National Tourist Office SNTO and Kümmerly and Frey, $70-89$.

Bless, R. 1984. Beiträge zur spät- und postglazialen Geschichte der Gletscher im nordöstlichen Mont Blanc Gebiet. Universität Zürich. Physische Geographie, 15.

Braithwaite, R.J. and F. Müller, 1980. On the parameterization of glacier equilibrium line altitude. In IAHS Publication 126, 263-271. Riederalp Workshop 1978 World Glacier Inventory.)

Driedger, C. L. and P. M. Kennard. 1986. Glacier volume estimation on Cascade volcanoes: an analysis and comparison with other methods. Ann. Glaciol., 8, 59-64.

Haeberli, W. 1983. Permafrost-glacier relationships in the Swiss Alpstoday and in the past. Permafrost Fourth International Conference. Proceedings July 17-22, 1983, Fairbanks, Alaska. Washington, DC, National Academy Press, 415-420.

Hacberli, W. 1985. Global land-ice monitoring: present status and future perspectives. In United States Department of Energy, Glaciers, Ice Sheets, and Sea Level: Effect of a CO-induced Climatic Change, Report of a IVorkshop held in Seattle, W'ashington, September 13-15, 1984. Washington, DC, National Academy Press, 216-231. Report DOE/EV 60235-1

Haeberli, W. 1994. Accelerated glacier and permafrost changes in the Alps. In Beniston, M., ed. Mountain emironments in changing climates. London and New York, Routledge, 91-107.

Haeberli, W. and J. Alean. 1985. Temperature and accumulation of high altitude firn in the Alps. Ann. Glaciol., 6, 161-163.

Haeberli, W. and P. Müller. 1988. Flucluations of Glaciers 1980-1985 ( Vol. V). A contribution to the Global Environmental Monitoring System (GEMS) and International Hydrological Programme. Paris, International Commission on Snow and Ice, International Association of Hydrological Sciences, United National Environment Programme and UNESCO. Report prepared for the World Glacier Monitoring Service.

Hacberli, W. and M. Hoelzle. comps. 1993. Fluctuations of glaciers 1985 1990 (Vol. VI). A contribution to the Global Environmental Monitoring System (GEMS) and International Hydrological Programme. Paris, 
International Commission on Snow and Ice, International Association of Hydrological Sciences, United National Environment Programme and UNESCO. (Report prepared for the World Glacier Monitoring Service.)

Hacberli, W., H. Bösch, K. Scherler, G. Ostrem and C. C. Wallén. eds. 1989. World glacier inventory: status 1988. A contribution to the Global Environmental Moniloring System (GEMS) and the International Hydrological Programme. Nairobi, Kenya, IAHS (ICSI)/UNEP/Unesco.

Hoelzle, M. 1994. Permafrost und Gletscher im OberengadinGrundlagen und Anwendungsbeispiele für automatisierte Schätzverfahren. Eidg. Tech. Hochscule, Zürich. Versuchsanst. Wasserbau, Hydrol. Glaziol. Mitt. 132.

Hoelzle, M. and M. Trindler. In press. Data management and applications. Into the second century of worldwide glacier monitoring - prospects and strategies. Paris, etc., IPHSRH Unesco.

Hooke, R. LeB., J.E. Gold and J. Brzozowski. 1983. Near-surface temperature near and below the equilibrium line on polar and subpolar glaciers. Z. Gletscherkd. Glazialgeol., 19, 1-25.

Jóhannesson, T., C. Raymond and E. Waddington. 1989. Time-scale for adjustment of glaciers to changes in mass balance. J. Glaciol., 35 (121), 355-369.

Kuhn, M. 1989. The response of the equilibrium line altitude to climatic fluctuations: theory and observations. In Oerlemans, J., ed. Glacier fluctuations and climatic change. Dordrecht, etc., Kluwer Academic Publishers, 407-417.

Kuhn, M. 1990. Energieaustausch Atmosphäre - Schnee und Eis. Eidg. Tech. Hochschule, Zürich. Versuchsanst. W'asserbau, Hydrol. Glaziol. Mitt., $108,21-32$.

Lliboutry, L. and L. Reynaud. 1981. "Global dynamics" of a temperate valley glacier, Mer de Glace, and past velocities deduced from Forbes' bands. J. Glaciol., 27 (96), 207-226.

Maisch, M. 1992. Die Gletscher Graubündens: Rekonstruktion und Auswertung der Gletscher und deren Veränderungen seit dem Hochstand von $1850 \mathrm{im}$ Gebiet der östlichen Schweizer Alpen (Bündnerland und angrenzende Regionen). Zürich, Geographisches Institut der Universität.

Müller, F., T. Caflisch and Müller. 1976. Firn und Eis der Schweizer Alpen: Gletscherimeentar. Zürich, Switzerland, etc., Eidgenössische Technische Hochschule.

Müller, P. 1988. Parametrisierung der Gletscher-Klima-Beziehung für die Praxis - Grundlagen und Beispiele. Eidg. Tech. Hochschule, Zürich. Versuchsanst. Wasserbau, Hydrol., Glaziol. Mitt. 95.

Nye, J.F. 1965. A numerical method of inferring the budget history of a glacier from its advance and retreat. F. Glaciol., 5 41), 589-607.

Oerlemans, J. 1993. Modelling of glacier mass balance. In Peltier, W. R., ed. Ice in the climate system. Berlin, etc., Springer-Verlag, 101-116.

Oerlemans, J. 1994. Quantifying global warming from the retreat of glaciers. Science, 264 (5156), 243-245.

Oerlemans, J. and J. P. F. Fortuin. 1992. Sensitivity of glaciers and small ice caps to greenhouse warming. Science, 258 (5079), 115-117.

Oerlemans, J. and N. C. Hoogendorn. 1989. Mass-balance gradients and climatic change. J. Glaciol., 35 (121), 399-405.

Paterson, W. S. B. 1981. The physics of glaciers. Second edition. Oxford, etc., etc., Pergamon Press.

Patzelt, G. and Aellen, M. 1990. Gletscher. Eidg. Tech. Hochschule, Zürich. Versuchsanst. Wasserbau, Hydrol. Glaziol. Mitt., 108, 4969.

Weertman, J. and G.E. Birchfield. 1983. Basal water film, basal water pressure, and velocity of traveling waves on glaciers. J. Glaciol., 29(101), 20-27. 